\title{
Chemical Characterization of Coffee Husks, a By-Product of Coffea arabica Production
}

\author{
Lais B. Cangussu ${ }^{1}\left(\mathbb{D}\right.$, Jean Carlos Melo ${ }^{1}$, Adriana S. Franca ${ }^{1,2, *(D)}$ and Leandro S. Oliveira ${ }^{1,2}$ \\ 1 Graduate Program in Food Science, Universidade Federal de Minas Gerais, Av. Antônio Carlos, 6627, \\ Belo Horizonte 31270-901, MG, Brazil; lai.sbc1@hotmail.com (L.B.C.); jeancarlosmelo1@hotmail.com (J.C.M.); \\ leandro@demec.ufmg.br (L.S.O.) \\ 2 Department of Mechanical Engineering, Universidade Federal de Minas Gerais, Av. Antônio Carlos, 6627, \\ Belo Horizonte 31270-901, MG, Brazil \\ * Correspondence: adriana@demec.ufmg.br; Tel.: +55-31-3409-3512
}

Citation: Cangussu, L.B.; Melo, J.C.; Franca, A.S.; Oliveira, L.S. Chemical Characterization of Coffee Husks, a By-Product of Coffea arabica Production. Foods 2021, 10, 3125. https: / /doi.org/10.3390/ foods 10123125

Academic Editors: Maria Eduardo-Figueira and João Rocha

Received: 4 November 2021 Accepted: 14 December 2021 Published: 16 December 2021

Publisher's Note: MDPI stays neutral with regard to jurisdictional claims in published maps and institutional affiliations.

Copyright: (c) 2021 by the authors. Licensee MDPI, Basel, Switzerland. This article is an open access article distributed under the terms and conditions of the Creative Commons Attribution (CC BY) license (https:// creativecommons.org/licenses/by/ $4.0 /)$.

\begin{abstract}
Coffee husks are a major by-product of coffee production and are currently being underutilized. The aim of this work was to chemically characterize coffee husks to allow for an adequate evaluation of their potential for valorization. Blanched and non-blanched coffee husks were characterized for extractable and non-extractable phenolics, caffeine, trigonelline content, and for their polysaccharide and proximal composition. The total, soluble and insoluble fiber contents were determined, together with the husks' technological properties. Antioxidant activity and bioaccessibility of phenolic compounds of coffee husks were evaluated. Two types of husk were studied: one comprised mostly of outer skin and pulp (CH1); and other comprised mostly of parchment (CH2). Blanching had positive effects on non-extractable phenolics, chlorogenic acid and on the bioaccessibility of phenolics, promoting small reductions in extractable phenolics, protocathecuic acid, caffeine and trigonelline contents. Blanched $\mathrm{CH} 1$ presented more appropriate properties than $\mathrm{CH} 2$ for potential applications in food. It also presented better antioxidant, hydration, and oil holding properties than those of other agri-food by-products. Tentatively identified polysaccharides included galactomannans, arabinogalactans type II, pectin and cellulose.
\end{abstract}

Keywords: agri-food by-products; dietary fiber; bioaccessibility; non-extractable phenolics; polysaccharides

\section{Introduction}

Coffee is one of the main commodities in the world in terms of revenue, second only to petroleum, being consumed by approximately a third of the world population [1,2]. Brazil, Vietnam, Colombia and Indonesia are the largest producers in the world [2]. Coffee processing generates large amounts of by-products. Dry processing is the most common technique applied to coffee fruits [2], with main by-product being comprised of dried pulp and parchment and it is herein denominated coffee husks $(\mathrm{CH})$. Dry processing generates approximately $1 \mathrm{~kg}$ of $\mathrm{CH}$ per $\mathrm{kg}$ of coffee beans produced [3]. The adequate allocation of these by-products contributes to a sustainable production, since these can cause serious environmental problems due to their content of highly bioactive compounds such as caffeine and trigonelline [4].

Coffee production by-products have been studied since the beginning of the twentieth century, mostly for applications as ingredients in animal feed and composting [3]. However, throughout the majority of the 20th century studies on such by-products were rather scarce and only recent have studies on these by-products as precursor materials to produce value-added products regained momentum [5-9]. A few products containing coffee byproducts are already being commercialized or are awaiting approval for commercialization as novel foods around the world as reviewed by Klingel et al. [10]. To define suitable processes for valorization of coffee husks, it is necessary to properly physicochemically 
characterize this by-product. Proximate compositions of coffee husks have been scarcely published in the literature $[3,6,11]$ with a rather large variability of the individual values for lipids $(0.5-3 \%)$, protein $(7-17 \%)$, ash $(3-7 \%)$ and carbohydrates $(16-85 \%)$ contents. A large variability is also observed for the published values for cellulose (14.7-46.1\%), hemicellulose (10.2-29.7\%) and lignin (10.1-34.2\%) contents [5,12-14]. Aside from inherent agronomical and processing variabilities, the major reason for the wide range of values for each class of compound is the lack of a proper definition of what is termed 'coffee husk'. The coffee fruit comprises several layers: outer skin (peel); pulp; mucilage; parchment; silverskin; and beans. When coffee is dry processed, the major wastes generated are the husks, which comprise dry pulp and parchment (including outer skin and mucilage). In wet processing, there are two separate wastes, generated in distinct steps of the processing: The wet pulp (including the outer skin); and the dry parchment (including a portion of the mucilage).

Extractable phenolics and other bioactive compounds were the classes of compounds more minutely studied in coffee husks, pulp and parchment, with identification and quantification of individual compounds, such as chlorogenic, ferulic and protocatechuic acids, rutin, catechin, epicatechin, anthocyanins and caffeine [15-19].

Polyphenols have received considerable interest due to their potent antioxidant activities [20] and are classified according to their structure as extractable phenols (EP) and non-extractable phenols (NEP), with the latter labeled macroantioxidants. Vegetable matrices, such as agri-food by-products, usually have higher contents of NEP than of EP [21]. However, NEP are hardly removed from the vegetable matrix when exposed to aqueous or organic solvents because they are entrapped in the matrix, strongly attached to polysaccharides and proteins $[22,23]$. The exploitation of the NEP fraction of agricultural by-products could allow surplus revenue for agricultural producers as the by-product is valorized. No studies on the non-extractable phenolics of coffee husks were found in the literature and the bioaccessibility of these by-products' bioactive compounds has not been evaluated to allow for a definition of a suitable application in the food industry. Furthermore, the polysaccharide fraction of coffee husks was not properly characterized, with published data restricted to sucrose and total reducing sugars contents $[3,5,6]$.

To evaluate the potential of minimally processed coffee husks, in the form of flour, as a functional food ingredient, there is a need to determine the bioaccessibility of its bioactive compounds. Hence, this study aimed at contributing to the evaluation of coffee husk flours as a potential source of dietary fibers and bioactive compounds by tentatively characterizing their polysaccharide fractions, by determining the contents of bioactive compounds, such as caffeine, trigonelline and phenolic compounds, and by investigating the bioaccessibility of the associated bioactive phenolic compounds.

\section{Materials and Methods}

\subsection{Reagents}

Standards for chromatography analyzes (ferulic acid, chlorogenic acid, caffeine, monosaccharides, D-allose) were obtained from Sigma-Aldrich (St. Louis, MO, USA), except protocatechuic acid, trigonelline (USP, São Paulo, Brazil) and D-(+)-xylose (Supelco, Bellefonte, PA, USA).

\subsection{Flours Preparation}

Two samples of husks, $\mathrm{CH} 1$ and $\mathrm{CH} 2$, obtained by dry processing of Bourbon Arabicas were used in this study: $\mathrm{CH} 1$, comprised of $80 \%$ peel and pulp and $20 \%$ parchment, was provided by the Coffee Industry Syndicate of the State of Minas Gerais (Belo Horizonte, Brazil); and $\mathrm{CH} 2$, comprised of $28 \%$ peel and pulp and $72 \%$ parchment, were provided by the Santa Inês Farm (Carmo de Minas, MG, Brazil). Husks were stored in plastic containers at $20^{\circ} \mathrm{C}$. Half the samples were blanched at $90 \pm 2{ }^{\circ} \mathrm{C}$ for $1 \mathrm{~min}$. The blanched $(\mathrm{CH} 1 \mathrm{~b}$ and $\mathrm{CH} 2 \mathrm{~b}$ ) and unblanched ( $\mathrm{CH} 1$ and $\mathrm{CH} 2)$ samples were dried in a convective oven for 
$6 \mathrm{~h}$ at $60 \pm 2{ }^{\circ} \mathrm{C}$ and, subsequently, ground, graded in a 35-mesh sieve (Tyler), and stored at $-18^{\circ} \mathrm{C}$.

\subsection{Extractable and Non-Extractable Phenolics}

Half a gram of husk powders was placed in $50 \mathrm{~mL}$ Falcon tubes and extraction of phenolics was performed by adding $20 \mathrm{~mL}$ of methanol $(50 \% \mathrm{v} / \mathrm{v})$ and $20 \mathrm{~mL}$ of acetone $(70 \% v / v)$. After each extraction, the samples were centrifuged at $3500 \times \mathrm{g} \mathrm{rpm}$ for $15 \mathrm{~min}$. The supernatants, comprising total extractable phenolics (TEP), were combined and the volume made up to $50 \mathrm{~mL}$ with distilled water [21]. The residues were dried at $35^{\circ} \mathrm{C}$ for $17 \mathrm{~h}$ and used in the determination of non-extractable phenolics (NEP).

Extractable phenolics were evaluated by the Folin-Ciocalteu method. $1 \mathrm{~mL}$ of extracts was combined with $1 \mathrm{~mL}$ of Folin-Ciocalteu reagent solution at a 1:3 ratio, $2 \mathrm{~mL}$ of sodium carbonate $(20 \% \mathrm{~m} / \mathrm{v})$, and $2 \mathrm{~mL}$ of distilled water. Samples were stirred and let to rest for $90 \mathrm{~min}$ in the dark. Absorbance values were measured at $700 \mathrm{~nm}$ in a UVVIS spectrophotometer (Micronal, São Paulo, Brazil) [21]. A calibration curve was built employing gallic acid and results expressed as gallic acid equivalents (mg GAE/g dry matter). Folin-Ciocalteu reagent reacts with reducing compounds, hence, quantification of phenolics by High Performance Liquid Chromatography (HPLC) was also carried out in our study. However, since this reagent/method has been employed for so long, not only for coffee and its by-products, but also for a variety of other agri-food by-products, it was used in this study to allow for comparison of the herein obtained results with those of other by-products from other studies. Also, aside from the not easily accessible reducing ends of long chain polysaccharides, there was no expectation of reducing compounds other than polyphenols (e.g., ascorbic acid, tocopherol and others) being present in significant amounts in coffee by-products.

Dry residues from the TEP extraction were mixed with $10 \mathrm{~mL}$ of n-butanol- $\mathrm{HCl}$ (95:5 v/v) containing $0.7 \mathrm{~g} / \mathrm{L}$ of $\mathrm{FeCl}_{3}$ and kept at $100{ }^{\circ} \mathrm{C}$ for $50 \mathrm{~min}$. The mixtures were centrifuged, and supernatants collected. Samples were washed twice with $5 \mathrm{~mL}$ of $\mathrm{n}$ butanol- $\mathrm{HCl}(95: 5 \mathrm{v} / \mathrm{v})$ containing $0.7 \mathrm{~g} / \mathrm{L}$ of $\mathrm{FeCl}_{3}$, centrifuged again, and supernatants collected. Volume was completed to $25 \mathrm{~mL}$ with butanol- $\mathrm{HCl}$ solution. Then, absorbance values were measured at 450 and $550 \mathrm{~nm}$ in a UV-Vis spectrophotometer. The sum of absorbance values was plotted against NEP concentration. The spectrophotometer was reset to zero with a white solution of n-butanol- $\mathrm{HCl}(95: 5 \mathrm{v} / \mathrm{v})$ containing $\mathrm{FeCl}_{3}$. Proanthocyanidin obtained from carob pods (Ceratonia siliqua L.) was used as standard [22]. Carob pods contain large amounts of proanthocyanidins and thus were utilized in our study as a source of this polymeric material, which was isolated using a variety of solvents (acetone, petroleum ether, methanol) assisted by ultrasonication, purified by chromatography (successive elution with methanol-water and acetone-water). The purity of the isolated proanthocyanidins was determined to be $76.5 \%$.

In vitro digestion of the flour was evaluated in oral, gastric, and small intestinal phases, according to Dutra et al. [24]. $500 \mathrm{mg}$ of husks flour were mixed with $12.5 \mathrm{~mL}$ saline solution $\left(0.05 \mathrm{~g} / \mathrm{mL}\right.$ of $\mathrm{Na}_{2} \mathrm{HPO}_{4}, 0.004 \mathrm{~g} / \mathrm{mL}$ of $\mathrm{KH}_{2} \mathrm{PO}_{4}, 0.16 \mathrm{~g} / \mathrm{mL}$ of $\mathrm{NaCl}$ and $0.17 \mathrm{~g}$ of $\alpha$-amylase). The samples were shaken at $95 \mathrm{rpm}$ in an orbital incubator for $10 \mathrm{~min}$ at $37^{\circ} \mathrm{C}$. Subsequently, the mixtures were acidified ( $\mathrm{pH}$ 2.5) with $\mathrm{HCl} 3 \mathrm{M}$, and $5 \mathrm{~mL}$ of pepsin preparation was added (13 $\mathrm{mg}$ of porcine pepsin in $5 \mathrm{~mL}$ of $\mathrm{HCl} 0.1 \mathrm{M}$ ). For gastric digestion simulation, samples were incubated for $1 \mathrm{~h}$ at $37^{\circ} \mathrm{C}$ under agitation at $95 \mathrm{rpm}$ and subsequently cooled in an ice bath. For the simulated small intestinal digestion, $\mathrm{pH}$ was adjusted to 7.5 with $\mathrm{NaHCO}_{3} 1 \mathrm{M}$, followed by addition of $5 \mathrm{~mL}$ of $\mathrm{NaHCO}_{3}$ $1 \mathrm{M}$ containing $87 \mathrm{mg}$ of pancreatin and $7 \mathrm{mg}$ of bile salts. The mixture was incubated at $37^{\circ} \mathrm{C}$ for $2 \mathrm{~h}$ under agitation, centrifuged at $3500 \times \mathrm{g}$ rpm for $10 \mathrm{~min}$, the supernatant was collected, and the volume was made up to $50 \mathrm{~mL}$ with distilled water. The extracts were 
used to quantify total extractable phenolics as previously described. The bioaccessibility percentage (\% Bio) was calculated by:

$$
\% \text { Bio }=\frac{b \times 100}{a}
$$

where $b$ is the quantity of phenolics released after in vitro digestion and $a$ is the quantity of phenolics prior to in vitro digestion.

\subsection{Identification and Quantification of Phenolic Compounds by High-Performance Liquid Chromatography (HPLC)}

Phenolic compounds extracts were obtained according to Dutra et al. [24]. Before extraction, chloroform was used to degrease the samples. $0.15 \mathrm{~g}$ of flour were extracted using different methanol concentrations ( $10 \mathrm{~mL}$ at $50 \%, 10 \mathrm{~mL}$ at $75 \%$, and $5 \mathrm{~mL}$ at $100 \%$ ) in a Dubnoff bath at $65{ }^{\circ} \mathrm{C}$ for $1 \mathrm{~h}$. After each extraction, samples were centrifuged at $3500 \times g$ rpm for $15 \mathrm{~min}$ and supernatants combined, with volume completed to $25 \mathrm{~mL}$ with methanol $100 \%$. Filtered samples were injected in a Prominence HPLC system (Shimadzu, Kyoto, Japan), using a Photodiode Array (PDA) detector (203-325 nm) and a Shimadzu C18 column $(4.6 \mu \mathrm{m} \times 150 \mathrm{~mm})$ (Shimadzu, Kyoto, Japan) at $50{ }^{\circ} \mathrm{C}$. The mobile phase consisted of water and acetonitrile (92.6:7) containing $0.4 \%$ phosphoric acid (phase A) and acetonitrile containing $0.4 \%$ phosphoric acid (phase B) at a flowrate of $1.2 \mathrm{~mL} / \mathrm{min}$. Gradient elution was performed as follows: 0-8 min, 1-3\% linear B; 8-12 min, 3-8\% linear B; $12-15 \mathrm{~min}, 8-10 \%$ linear B; $15-20 \mathrm{~min}, 10-15 \%$ linear B; $20-25 \mathrm{~min}, 15-40 \%$ linear B; 25-30 min, 40-80\% linear B; 30-35 min, 80-95\% linear B; 35-35.1 min, 95-1\% linear B and $35.1-42 \mathrm{~min} .-1 \%$ B isocratic. Phenolic compounds were identified by retention times and UV spectra of respective standards. Quantification was based on the standard curves.

\subsection{Quantification of Caffeine and Trigonelline}

Extraction of trigonelline and caffeine was conducted according to Perrone et al. [25]. We mixed $10 \mathrm{~mL}$ of boiling water with $0.1 \mathrm{~g}$ of sample. Samples were conditioned in a Dubnoff bath at $100{ }^{\circ} \mathrm{C}$ for $10 \mathrm{~min}$ under agitation. The mixtures were centrifuged for $10 \mathrm{~min}$ and supernatants collected. The extraction was repeated, and volume completed to $50 \mathrm{~mL}$. Extracts were diluted $(0.0004 \mathrm{~g} / \mathrm{mL})$, filtered $(0.20 \mu \mathrm{m}$ filters $)$ and analyzed by HPLC using a PDA detector ( $264 \mathrm{~nm}$ for trigonelline; $272 \mathrm{~nm}$ for caffeine) and a Shimadzu C18 $5 \mu \mathrm{m}(4.6 \mu \mathrm{m} \times 150 \mathrm{~mm})$ column at $18^{\circ} \mathrm{C}$. Mobile phases were water:methanol (95:5) for trigonelline and methanol:water (40:60) for caffeine, at a flowrate of $1 \mathrm{~mL} / \mathrm{min}$. Identification of caffeine and trigonelline was based on retention time and UV spectrum of individual standards, and quantification was based on calibration curves of respective standards.

\subsection{Monosacharides Profile}

Neutral monosaccharides composition was determined by gas chromatography, according to Leão et al. [26] $5 \mathrm{mg}$ of samples were hydrolized with $0.5 \mathrm{~mL}$ of trifluoroacetic acid $(2 \mathrm{~mol} / \mathrm{L})$. Subsequently, the resulting monosaccharides were reduced using $1 \mathrm{~mL}$ of sodium borohydride $0.5 \mathrm{~mol} / \mathrm{L}$ in dimethylsulfoxide and derivatized to alditol acetates by adding $2 \mathrm{~mL}$ of acetic anhydride and $200 \mu \mathrm{L}$ of 1-methylimidazole. Alditol acetates were extracted using $1 \mathrm{~mL}$ of dichloromethane and analyzed in a gas chromatograph (Varian 3900, Palo Alto, CA, USA) with Flame Ionization Detector (FID) and BPX-70 capillary column $(30 \mathrm{~m} \times 0.32 \mathrm{~mm} \times 0.25 \mu \mathrm{m})$. Temperatures of the detector and injector were 280 and $230{ }^{\circ} \mathrm{C}$, respectively. Carrier gas was nitrogen with flowrate of $1.5 \mathrm{~mL} / \mathrm{min}$ for $38 \mathrm{~min}\left(30 \mathrm{~s}\right.$ at $38^{\circ} \mathrm{C}$, temperature increased to $170{ }^{\circ} \mathrm{C}$ at a rate of $50{ }^{\circ} \mathrm{C} / \mathrm{min}$, then increased to $230{ }^{\circ} \mathrm{C}$ at a rate of $2{ }^{\circ} \mathrm{C} / \mathrm{min}$, and finally maintained for $5 \mathrm{~min}$ ). Identification of the monosaccharides was undertaken using the respective standards. The relative molar ratio of the monosaccharides was calculated with respect to allose, employed as internal standard. 


\subsection{Chemical, Physical and Technological Properties}

Proximate composition of the flour was evaluated by AOAC methods [27]. Moisture contents were determined after sample drying at $105^{\circ} \mathrm{C}$, until constant weight. Fat contents were determined by Soxhlet method after extraction with petroleum ether (AOAC method 4.5.05). Ash contents were determined by burning at $550{ }^{\circ} \mathrm{C}$ until obtaining white ashes (AOAC method 942.05). Crude protein was determined by the Kjeldahl method (AOAC method 960.52) using the 6.25 factor with subtraction of caffeine and trigonelline contents. Total dietary fiber (TDF) was determined by enzymatic-gravimetric method (AOAC methods 985.29 and 960.52). Samples were mixed with $\alpha$-amylase at $100{ }^{\circ} \mathrm{C}$ for $15 \mathrm{~min}$ and digested with pepsin and pancreatin at $40^{\circ} \mathrm{C}$, for $60 \mathrm{~min}$ each. Insoluble dietary fiber (IDF) was filtered and washed with hot distilled water. Ethanol $95 \%$ at $60{ }^{\circ} \mathrm{C}$ was added to the filtrate and allowed to rest for $60 \mathrm{~min}$ to precipitate the soluble dietary fiber (SDF). IDF and SDF residues were dried at $105^{\circ} \mathrm{C}$ for $16 \mathrm{~h}$. TDF corresponded to the sum of IDF and SDF. Pectin content was determined by extraction with $\mathrm{HCl}$ followed by addition of $\mathrm{NaOH}$ to precipitate pectin ( $\mathrm{pH} 3.5$ ). Pectin precipitates were washed with propanol $70 \%$, submitted to overnight drying at $65^{\circ} \mathrm{C}$ and weighed.

In vitro antioxidant capacity was evaluated according to methods based on radical scavenging activity ABTS ${ }^{\bullet+}$ (2,2'-azino-bis(3-ethylbenzothiazoline-6-sulfonate radical cation) and FRAP (Ferric Antioxidant Power) assays [26,28]. For all methods, the phenolic extracts were diluted with different volumes of ethanol: $1 / 0.5 ; 1 / 1.0 ; 1 / 1.5 ; 1 / 2.0$ and $1 / 2.5$ (volume of extract/volume of ethanol). The control solution was prepared by mixing ethanol and the respective standard solution.

Color was analyzed by a Hunter ColorFlex colorimeter (Reston, VA, USA) with D65 standard illumination and $10^{\circ}$ observer angle. CIE L*a*b* color coordinates were converted to chroma $\left(\mathrm{c}^{*}\right)$ and hue angle $(\mathrm{h})$.

Microstructures of $\mathrm{CH}$ samples were observed by a JEOL JSM-5510 scanning electron microscope (SEM) (JEOL, Tokyo, Japan) at magnifications of $1000 \times$. Coffee husk flours were dehydrated in an oven at $40^{\circ} \mathrm{C}$, for $24 \mathrm{~h}$, and placed on SEM specimen tubs with double adhesive tape and coated with a $10 \mathrm{~nm}$ gold layer.

One milligram of flour was mixed with $10 \mathrm{mg}$ of $\mathrm{KBr}$ and the spectra collected by IRAffinity-1 FTIR Spectrophotometer (Shimadzu, Japan) with a DLATGS detector with a $4 \mathrm{~cm}^{-1}$ resolution. $\mathrm{KBr}$ was utilized as background spectrum. Readings were carried out in dry atmosphere at $20^{\circ} \mathrm{C}$. Diffuse reflectance (DR) measurements were performed using a Shimadzu diffuse reflectance sampling accessory (DRS8000A).

Swelling capacity (SWC), water holding capacity (WHC), and oil holding capacity $(\mathrm{OHC})$ were determined according to Resende et al. [28]. For SWC determination, $1 \mathrm{~g}$ of sample was combined with $100 \mathrm{~mL}$ of distilled water. Suspension was incubated at $230 \mathrm{rpm}$ for $120 \mathrm{~min}$ and set for decantation for $18 \mathrm{~h}$. The volume occupied by the samples was recorded and expressed as $\mathrm{mL} / \mathrm{g}$ of sample. For WHC and OHC determinations, $25 \mathrm{~mL}$ of distilled water or soybean oil were mixed to $1 \mathrm{~g}$ of sample. The mixture was stirred at $150 \mathrm{rpm}$ for $18 \mathrm{~h}$ and centrifuged at $3500 \times \mathrm{g} \mathrm{rpm}$ for $30 \mathrm{~min}$. The supernatant was discarded, and the sample weighed. WHC and $\mathrm{OHC}$ were expressed as g water or oil/g of sample. SWC and WHC were also evaluated at $37^{\circ} \mathrm{C}$ in isotonic solutions $(\mathrm{NaCl}$ $0.9 \% \mathrm{~m} / \mathrm{v})$, simulating conditions inside the stomach $(\mathrm{pH}=1.5)$, duodenum $(\mathrm{pH}=8.5)$ and also in $\mathrm{pH}=7$ in order to verify the effect of surrounding medium on hydration properties of $\mathrm{CH}$ samples.

\subsection{Statistical Analysis}

Analyses were performed in technical triplicates. Data were statistically analyzed by ANOVA and Tukey $(p<0.05)$ methods by IBM SPSS software (version 19). The normality of data was verified using the Shapiro-Wilk test. 


\section{Results}

\subsection{Phenolic Compounds}

Data for contents of extractable (TEP) and non-extractable phenolic (NEP), chlorogenic acid (CGA), protocatechuic acid (APC), caffeine. trigonelline, and for bioaccessibility of phenolics in coffee husks $(\mathrm{CH})$ are shown in Table 1. $\mathrm{CH} 2$ and $\mathrm{CH} 2 \mathrm{~b}$ samples presented lower TEP values than $\mathrm{CH} 1$ and $\mathrm{CH} 1 \mathrm{~b}$, indicating coffee parchment contains lower contents of TEP than the outer skin and pulp. High concentration of phenolics in the outer skin is expected since the primary function of these metabolites is protection against external threats [26]. Thus, $\mathrm{CH} 1$ samples could be classified as a product with high content of phenolics ( $>500 \mathrm{mg} \mathrm{GAE} / 100 \mathrm{~g}$ ) [29], comparable to other fruits by-products such as buriti peels (785.1-934.6 mg GAE/100 g) [28]. Blanched samples presented lower TEP values than unblanched ones. Blanching is a pretreatment used to inactivate polyphenoloxidase enzymes responsible for the oxidation of phenolic compounds, thus favoring the maintenance of their antioxidant potential. However, it also favored the degradation of TEP compounds in $\mathrm{CH}$, indicating these phenolic compounds were sensitive to the temperature applied during blanching [28].

Table 1. Extractable (TEP) and non-extractable (NEP) phenolics, bioaccessibility of phenolics (TEP \%), chlorogenic acid (CGA), protocatechuic acid (PCA), caffeine and trigonelline in coffee husks.

\begin{tabular}{|c|c|c|c|c|c|c|c|}
\hline Sample & $\begin{array}{c}\text { TEP } \\
\text { (mg GAE/100 g) }\end{array}$ & $\begin{array}{c}\text { NEP } \\
(\mathrm{mg} / 100 \mathrm{~g})\end{array}$ & $\begin{array}{c}\text { CGA } \\
(\mathrm{mg} / 100 \mathrm{~g})\end{array}$ & $\begin{array}{c}\text { PCA } \\
(\mathrm{mg} / 100 \mathrm{~g})\end{array}$ & $\begin{array}{c}\text { Bioaccessibility } \\
\text { TEP \% }\end{array}$ & $\begin{array}{l}\text { Caffeine } \\
(\mathrm{mg} / 100 \mathrm{~g})\end{array}$ & $\begin{array}{l}\text { Trigonelline } \\
\text { (mg/100 g) }\end{array}$ \\
\hline $\mathrm{CH} 1$ & $983.05 \pm 32.68^{a}$ & $2025.85 \pm 55.68^{c}$ & $121.55 \pm 0.18^{b}$ & $28.24 \underset{\mathrm{a}}{ \pm} 0.18$ & 70.76 & $618.10 \pm 6.66^{b}$ & $542.80 \pm 6.54^{a}$ \\
\hline $\mathrm{CH} 1 \mathrm{~b}$ & $904.74 \pm 9.47^{b}$ & $2703.33 \pm 10.73^{a}$ & $174.27 \pm 0.26^{\mathrm{a}}$ & $14.42 \underset{\mathrm{b}}{ \pm} 0.01$ & 68.64 & $522.09 \pm 0.62^{c}$ & $285.58 \pm 4.83^{b}$ \\
\hline $\mathrm{CH} 2$ & $274.77 \pm 6.35^{c}$ & $1837.77 \pm 23.73^{\mathrm{d}}$ & $17.19 \pm 0.13^{\mathrm{d}}$ & - & 65.74 & $696.22 \pm 4.86^{\mathrm{a}}$ & $246.21 \pm 2.56^{c}$ \\
\hline $\mathrm{CH} 2 \mathrm{~b}$ & $196.31 \pm 12.54^{\mathrm{d}}$ & $2387.34 \pm 32.88^{b}$ & $43.09 \pm 0.16^{c}$ & - & 64.10 & $418.13 \pm 0.65^{\mathrm{d}}$ & $120.16 \pm 1.20^{\mathrm{d}}$ \\
\hline
\end{tabular}

Mean \pm standard deviation $(n=3)$. Different letters in the same column indicate that values are significantly different $(p>0.05)$.

Blanched $\mathrm{CH}$ samples presented NEP values higher than those of unblanched samples, confirming that polyphenoloxidases could be inactivated by heat treatment, preserving NEP. Also, these compounds were more strongly bound to the plant matrix, being somewhat protected from the high temperature during blanching. The increase of NEP contents with blanching is attributed to the removal of soluble solids, which decreased the dry basis mass. NEP contents of all samples were significantly higher than those of other fruit by-products, such as pequi $(346.84 \mathrm{mg} / 100 \mathrm{~g})$, apple (1278.7 mg/100 g), kiwi (1522.0 mg/100 g), melon (316.2 mg/100 g), nectarine (1797.5 mg/100 g), pear $(721.1 \mathrm{mg} / 100 \mathrm{~g})$, and watermelon $(305.3 \mathrm{mg} / 100 \mathrm{~g})$ [26,30]. In addition, NEP contents for blanched samples were comparable to that for grape bagasse $(2716 \mathrm{mg} / 100 \mathrm{~g})$, which was considered a by-product with a high content of non-extractable phenolics [22].

Chlorogenic (CGA) and protocatechuic (PCA) acids are phenolic compounds that exhibit a variety of biological functions in the human body, such as anti-inflammatory, antioxidant, and anticarcinogenic bioactivities [31,32]. CGA was identified in all $\mathrm{CH}$ samples, whereas only traces of PCA were detected in $\mathrm{CH} 2$ samples (Table 1, associated chromatograms in Figures 1 and 2, respectively). CGA contents were considerably higher than those of other phenolics in coffee by-products [33]. Performing qualitative and quantitative PCA analyzes in complex matrices, such as foods, is difficult due to its low concentration and coelution with interferents in HPLC analysis [31]. $\mathrm{CH} 2$ and $\mathrm{CH} 2 \mathrm{~b}$ samples presented CGA values significantly lower than $\mathrm{CH} 1$ and $\mathrm{CH} 1 \mathrm{~b}$, and blanched samples presented higher values of CGA than unblanched ones. These compounds were also preserved due to inactivation of polyphenoloxidases during the blanching step. CGA can also form complexes with carbohydrates or be bound to proteins present in the $\mathrm{CH}$ matrix, increasing their thermal stability and hindering degradation [34]. PCA content for $\mathrm{CH} 1 \mathrm{~b}$ was lower than for $\mathrm{CH1}$, suggesting this compound was more susceptible to degradation during blanching. Despite this, $\mathrm{CH} 1$ samples showed higher PCA contents than other fruits, such as apple $(1.3 \mathrm{mg} / 100 \mathrm{~g})$, peach $(1.24 \mathrm{mg} / 100 \mathrm{~g})$, and nectarine $(1.4 \mathrm{mg} / 100 \mathrm{~g})$ [21]. 

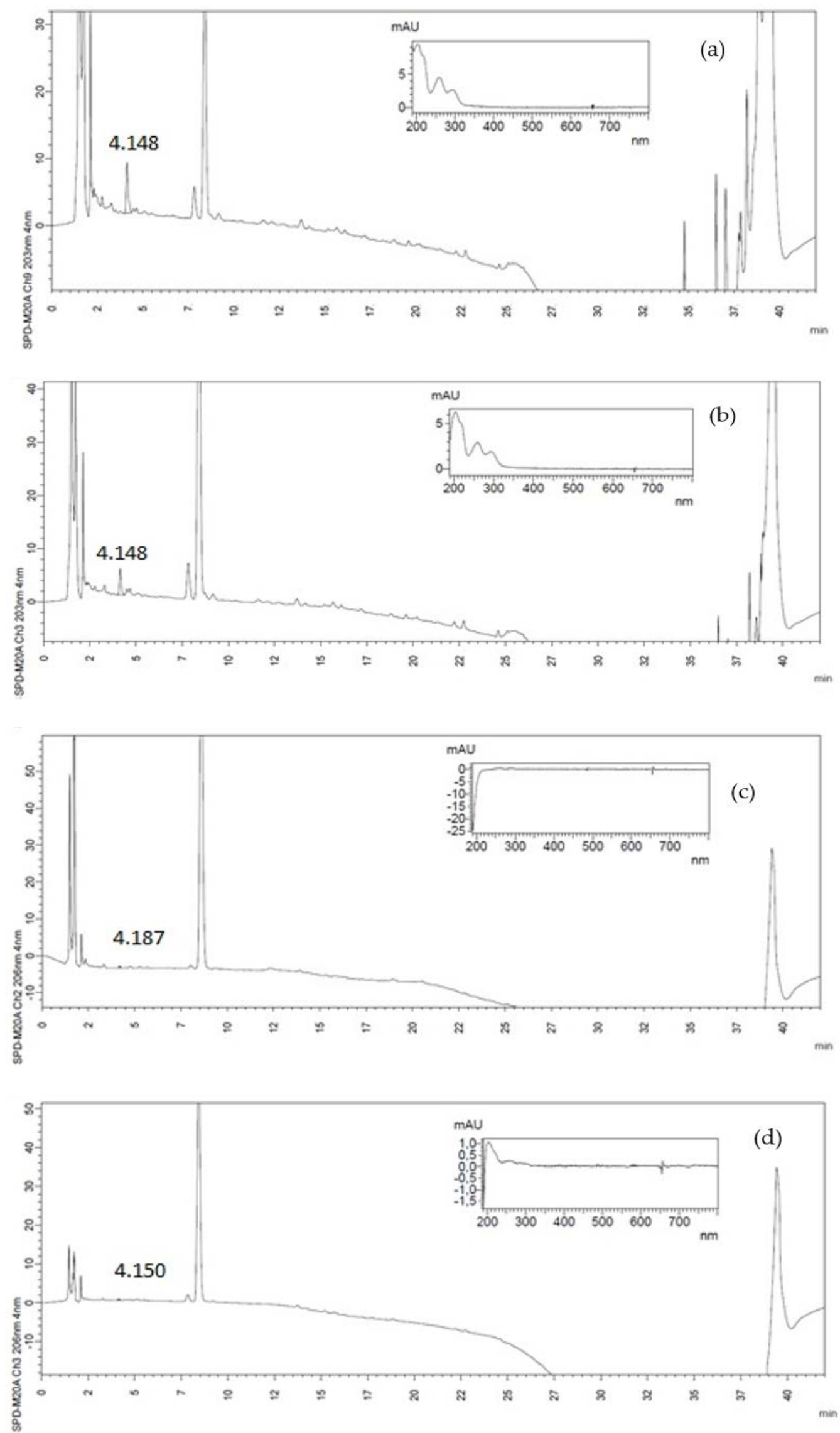

Figure 1. Protocathecuic acid (PCA) chromatograms and ultraviolet-visible (UV-Vis) spectra for (a) CH1, (b) CH1b, (c) CH2 and (d) $\mathrm{CH} 2 \mathrm{~b}$, respectively at $206 \mathrm{~nm}$. 

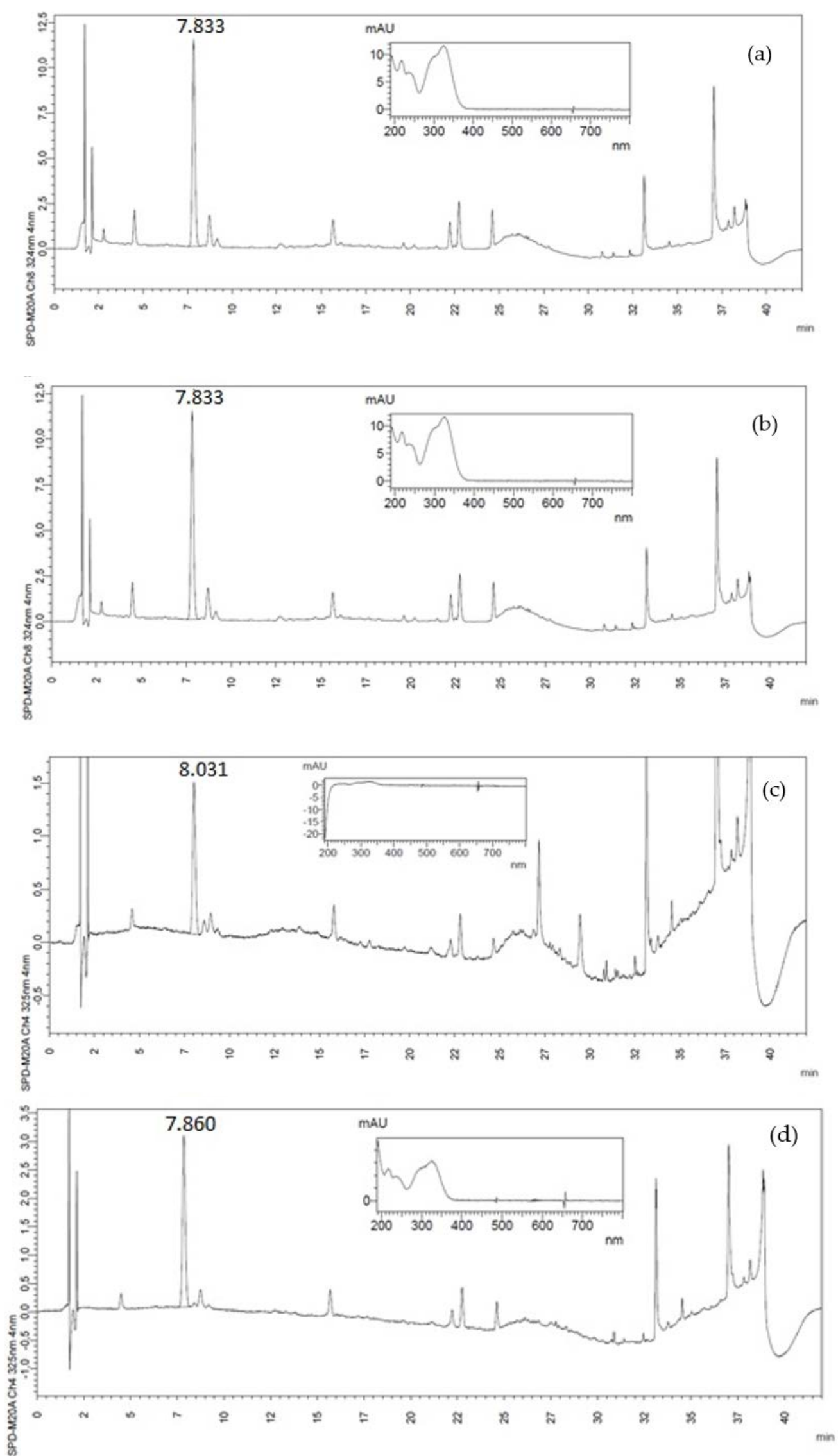

Figure 2. Chlorogenic acid (CGA) chromatograms and spectra for (a) $\mathrm{CH} 1,(\mathbf{b}) \mathrm{CH} 1 \mathrm{~b},(\mathbf{c}) \mathrm{CH} 2$ and (d) $\mathrm{CH} 2 \mathrm{~b}$, respectively at $325 \mathrm{~nm}$. 
Simulated buccal, gastric, and duodenum digestion of $\mathrm{CH}$ were performed to evaluate polyphenols stability under physiological conditions. Most studies have determined the bioactive properties of phenolic compounds without considering their physicochemical modifications after being submitted to digestive conditions. Besides, assessing the bioaccessibility of bioactive compounds is also important to further evaluate their actual availability in the human body. Bioaccessibility values of phenolics in coffee husks ranged from $64.10 \%$ to $70.76 \%$, indicating most phenolic compounds in $\mathrm{CH}$ flours were bioaccessible. The interactions of polyphenols with lipids, proteins and cell wall polysaccharides (CPS) can significantly affect the respective bioaccessibility, bioavailability, and bioefficacy $[35,36]$. Although polyphenols can interact with lipids by hydrophobic bonding, and hydrogen and covalent bonds [36], the content of lipids in the coffee husks studied herein is rather low and interactions of such types might be considered negligible. Investigations of interactions of polyphenols with proteins in cell walls by other researchers have led to the conclusion that proteins do not cause significant effects on polyphenol adsorption under the studied conditions [35]. Therefore, it can be safely assumed that the bioaccessibility of the phenolic compounds in our study was mostly determined by interactions of polyphenols with cell wall polysaccharides. Strong evidence indicates that CPS-polyphenol interactions can be significantly affected by physicochemical characteristics of both constituents [35]. The chemical composition, molecular weight, degree of esterification, the type of side chains and branching ratios, and porosity of cell wall polysaccharides and the solubility, molecular weight, functional groups, and conformation of polyphenols are the major factors affecting the interactions of CPS and polyphenols. Benitez et al. [37], in their study of coffee parchment as a source of dietary fiber, determined that xylose was the predominant monosaccharide in the dietary fiber fraction of coffee parchment. It was also determined that galactomannans and arabinogalactans were not present in the parchment dietary fiber fraction since arabinose and galactose were not, therein, detected. Furthermore, cellulose was determined to be the second most abundant polysaccharide in coffee parchment. Pectic polysaccharides, comprised solely of uronic acids, were the less abundant polysaccharides (4-7\% of coffee parchment composition) and the majority was linked to the cellulose matrix. Lignin content of coffee parchment was also significant (27-32\%). Reichembach and Petkowicz [38] investigated coffee pulp as a source of pectin and concluded that pectin content in the alcohol insoluble fraction was about $14.6 \%$. Cellulose and hemicelluloses have been deemed to present relatively lower affinities for polyphenols than pectins in solution or suspension [35]. Interactions of CPS with polyphenols most commonly occurs through electrostatic forces (i.e., non-covalent bonds) and hydrogen bonds as Van der Waals forces between hydroxyl groups of the phenolic compounds and different functionalities of the polysaccharides [36]. Although pectin may be present twice as much in coffee pulp and peel than in parchment $[37,38]$ and the amount of negatively charged arabinoxylans probably twice as much in parchment than in coffee pulp and peel (see Section 3.3), any differences in interactions of these polysaccharides with the polyphenols might have been compensated by the distinct proportions of pulp and peel and parchment in samples $\mathrm{CH} 1$ and $\mathrm{CH} 2$ (or $\mathrm{CH} 1 \mathrm{~b}$ and $\mathrm{CH} 2 \mathrm{~b}$ ), culminating in rather close values for bioaccessibility of polyphenols for both types of samples. Any attempt to further explain the small differences in bioaccessibility of polyphenols (4 to 5 percentage points) for the $\mathrm{CH} 1$ and $\mathrm{CH} 2$ samples herein studied would be pure speculation since no rigorous study was carried out on the specific factors that affect CPS-polyphenols interactions.

\subsection{Trigonelline and Caffeine}

Caffeine and trigonelline are important bioactive compounds in coffee beans [4]. They are soluble in water; therefore, a considerable amount of these components can be leached in industrial processes that use water, such as in the herein blanching step. The loss of caffeine and trigonelline in the blanching step depends on processing time and water temperature, which must be less than the values applied in their extraction processes. Herein, the samples were exposed to hot water for only $1 \mathrm{~min}$; however, significant losses 
of both compounds occurred (Table 1). Loss of trigonelline (47.4\% for CH1 and 51.2\% for $\mathrm{CH} 2$ ) was significantly higher than the loss of caffeine (15.5\% for $\mathrm{CH} 1$ and $40 \%$ for $\mathrm{CH} 2)$, since trigonelline is a zwitterion readily soluble in water, whereas caffeine is moderately soluble in water with a slight increase in solubility with temperature and with formation of complexes with chlorogenic acid. Other studies have determined caffeine and trigonelline contents in green coffee to be $919 \mathrm{mg} / 100 \mathrm{~g}$ and $1029.9 \mathrm{mg} / 100 \mathrm{~g}$, respectively [1,25]. Thus, caffeine and trigonelline contents in Arabica coffee husks amounts to more than half of those in coffee beans. Even with the loss of trigonelline after blanching, the processed byproducts still present high trigonelline contents when compared to other relevant sources, such as fenugreek seeds (0.17-0.28\%). Trigonelline is an important bioactive compound to humans due to its neuroprotective, hypolipidemic, antidiabetic, antihypertensive, and kidney, liver and heart protective activities [39].

\subsection{Characterization of Polysaccharides}

The identification of monosaccharides is relevant for determining the structure of the polysaccharides present in coffee husks. The relative molar percentages ( $\% \mathrm{~mol}$ ) of monosaccharides identified in the $\mathrm{CH}$ samples are presented in Table 2. In general, the samples comprised mostly of the outer skin ( $\mathrm{CH} 1$ and $\mathrm{CH} 1 \mathrm{~b})$ presented arabinose, mannose, and glucose contents higher than those comprising mostly parchment $(\mathrm{CH} 2$ and $\mathrm{CH} 2 \mathrm{~b}$ ). No differences in rhamnose and galactose contents were observed among them. These monosaccharides in the by-products can indicate the presence of polysaccharides similar to those present in coffee beans, such as galactomannans (galactose, mannose, and traces of glucose and arabinose) and arabinogalactans (arabinose, galactose, and traces of rhamnose) $[40,41]$.

Table 2. Relative molar percentages (RMP) of monosaccharides in coffee husks (CH).

\begin{tabular}{ccccc}
\hline Monosaccharides & CH1 (\% mol) & CH1b (\% mol) & CH2 (\% mol) & CH2b (\% mol) \\
\hline Rhamnose & $3.04 \pm 0.60^{\mathrm{a}}$ & $2.98 \pm 0.52^{\mathrm{a}}$ & $2.66 \pm 0.38^{\mathrm{a}}$ & $2.46 \pm 0.58^{\mathrm{a}}$ \\
Arabinose & $25.24 \pm 1.37^{\mathrm{a}}$ & $25.17 \pm 1.26^{\mathrm{a}}$ & $17.91 \pm 1.77^{\mathrm{b}}$ & $16.14 \pm 1.77^{\mathrm{b}}$ \\
Xylose & $32.92 \pm 1.46^{\mathrm{b}}$ & $23.69 \pm 1.17^{\mathrm{c}}$ & $55.53 \pm 1.89^{\mathrm{a}}$ & $53.66 \pm 1.87^{\mathrm{a}}$ \\
Mannose & $9.67 \pm 0.90^{\mathrm{a}}$ & $10.00 \pm 1.10^{\mathrm{a}}$ & $5.33 \pm 0.96^{\mathrm{b}}$ & $4.47 \pm 0.86^{\mathrm{b}}$ \\
Galactose & $11.91 \pm 2.40^{\mathrm{ab}}$ & $13.69 \pm 1.78^{\mathrm{a}}$ & $9.59 \pm 2.32^{\mathrm{b}}$ & $10.52 \pm 1.39^{\mathrm{b}}$ \\
Glucose & $15.84 \pm 1.32^{\mathrm{b}}$ & $22.92 \pm 1.28^{\mathrm{a}}$ & $8.68 \pm 0.92^{\mathrm{d}}$ & $12.74 \pm 1.23^{\mathrm{c}}$ \\
Myo-inositol & $1.38 \pm 0.12^{\mathrm{a}}$ & $1.54 \pm 0.17^{\mathrm{a}}$ & $0.30 \pm 0.04^{\mathrm{b}}$ & 0 \\
\hline
\end{tabular}

Mean \pm standard deviation $(n=3)$. Different letters in the same line indicate that values are significantly different $(p>0.05)$.

All samples showed high percentages of xylose, indicating the presence of xylans and xyloglucans in CH. Xyloglucans also have glucose and might have galactose in their structure. Thus, samples that showed higher percentages of xylose and lower percentages of glucose and galactose ( $\mathrm{CH} 2$ and $\mathrm{CH} 2 \mathrm{~b}$ ) probably contain more xylans (or arabinoxylans) and fewer xyloglucans (xylose and glucose). Only arabinose (19.93 $\mathrm{mol} \%)$, mannose $(4.43 \mathrm{~mol} \%)$, galactose $(60.27 \mathrm{~mol} \%)$ and glucose $(15.37 \mathrm{~mol} \%)$ were found in spent coffee grounds [41], and this fact shows that xylose is present only in the husks and is thus used to detect and identify adulteration of roasted and ground coffee with coffee husks.

Blanching caused an increase in glucose percentages in $\mathrm{CH}$ samples. This treatment causes softening of the vegetable matrix, probably due to hydrolysis of polysaccharides. Thus, glucose in $\mathrm{CH}$ samples can be released after hydrolysis of polysaccharides such as hemicellulose, pectin, and cellulose at high temperatures. In general, samples showed traces of myo-inositol, and these results were similar to the contents of myo-inositol in fresh pulp of lemon, tangerine, orange, and grape (0.6-2.1\%) [42]. Myo-inositol is a glucose isomer abundant in cereals and fruits, and deficient in foods of animal origin [43]. Thus, samples with high glucose contents $(\mathrm{CH} 1)$ presented myo-inositol contents higher than those with low glucose contents (CH2) (Table 2). Studies have shown that myo-inositol 
presented bioactivities in humans, such as reducing rates of gestational diabetes, and preventing depression and panic syndrome [44].

The FTIR spectrum of CH2b in the range of 1250 to $700 \mathrm{~cm}^{-1}$ (polysaccharide fingerprint region) and its second and fourth derivatives (absolute values of negative peaks) are presented in Figure 3 and, in conjunction with the monosaccharide composition results, is herein employed to tentatively characterize the polysaccharides present in coffee husks. This region is characterized by broad bands in the original spectrum, making it difficult to analyze. The results for monosaccharide composition demonstrated that coffee husks flour is comprised of different hemicellulotic and pectic polysaccharides, thus, overlapping and shifting of a few band peaks is expected since most of these polysaccharides have common types of linkage and functional groups and they interact with each other in the cell wall matrix. However, characteristic absorption bands of a specific polysaccharide or respective individual components allow for its discrimination from the others. Thus, the second derivative of the spectrum was taken and analyzed. The second derivative has the advantage of resolving the peaks that are lumped into the broad bands in the original spectrum and the wavenumbers of the local maxima of its negative peaks coincide with the wavenumbers of the local maxima of the peaks in the original spectrum. The fourth derivative was also taken since there were still a few overlapping peaks in the second derivative. The presence of pectic polysaccharides in $\mathrm{CH} 2 \mathrm{~b}$ is corroborated by the peak maxima at 1233, 1138, 1107, 1070, 1016, 897 and $829 \mathrm{~cm}^{-1}$ [45-47]. There are no bands at the vicinity of $878 \mathrm{~cm}^{-1}$ (characteristic of mannuronic acid) and rhamnose was detected in reasonable amounts in the samples, hence, it can be safely inferred that the pectic polysaccharides in coffee husks are of the rhamnogalacturonan type, since the bands at 1107 and $1016 \mathrm{~cm}^{-1}$ are characteristic of homogalacturonan content in pectin [48] and the peak at $829 \mathrm{~cm}^{-1}$ is attributed to out of plane hydroxyl vibrations characteristic of $\alpha$-linkage between $(1 \rightarrow 4)$ galacturonic acid units in the backbone of pectin [47]. Also, the bands at 1233 and $1016 \mathrm{~cm}^{-1}$ are, respectively, attributed to bending of hydroxyl in pyranose ring of pectin and to $\mathrm{C}-\mathrm{O}$ and $\mathrm{C}-\mathrm{C}$ stretching vibrations in pectin [47]. The presence of cellulose is corroborated by the absorption bands 1204, 1103, 1095, 1055, 1028, 1000 and $897 \mathrm{~cm}^{-1}$, with the wavenumber $897 \mathrm{~cm}^{-1}$ corresponding to $\mathrm{C} 1$ group frequency or ring frequency, characteristic peak of $\beta$-glycosidic linkages in sugar units, $1000 \mathrm{~cm}^{-1}$ characteristic of $C-O$ and $C-C$ stretching in cellulose [47] and $1028 \mathrm{~cm}^{-1}$ attributed to stretching vibrations of $\beta-(1 \rightarrow 4)$ glycosidic linkage of glucans [48]. Arabinogalactans type II are characterized by the absorption bands 1138, 1078, 1065, 1044, 1020, 978, 964 and $891 \mathrm{~cm}^{-1}$, with $1044 \mathrm{~cm}^{-1}$ attributed to steric interaction between side-chain arabinofuranosyl units and galactopyranosyl backbone at $1078 \mathrm{~cm}-1$ in arabinogalactan type II [48], 1138 and $978 \mathrm{~cm}^{-1}$ attributed to $\alpha-(1 \rightarrow 3)$ glycosidic links of side-chain arabinose [46] and $891 \mathrm{~cm}^{-1}$ attributed to stretching vibration of anomeric $\mathrm{C}-\mathrm{H}$ of $\beta$-galactopyranosyl units in the arabinogalactan backbone [49]. Galactomannans are characterized by the wavenumbers 1090, 1061, 1033, 897, 870, 816, 770, 747, 740 and $717 \mathrm{~cm}^{-1}$ with 1090 and $1061 \mathrm{~cm}^{-1}$ corresponding to stretching vibrations of $\mathrm{C}-\mathrm{O}-\mathrm{C}$ in $\beta-(1 \rightarrow 4)$ links of mannan polymers and $1033 \mathrm{~cm}^{-1}$ attributed to $C-C$ bonds of mannose unit rings [50]. The band $870 \mathrm{~cm}^{-1}$ is characteristic of sidechain $(1 \rightarrow 6)$ - $\alpha$-D-galactopyranosyl units in mannan backbone and the band $816 \mathrm{~cm}^{-1}$ attributed to $(1 \rightarrow 4)-\beta$-D-mannopyranosyl units in the backbone of galactomannans [51]. The wavenumbers 770, 747, 740 and $717 \mathrm{~cm}^{-1}$ correspond to the skeletal bending of galactose rings and to $\mathrm{C}-\mathrm{O}-\mathrm{C}$ bending vibration separately in galactomannan glycosidic linkages [49]. The peaks at 1171, 1121, 1078, 1072, 1049, 1040, 955, 930 and $891 \mathrm{~cm}^{-1}$ are suggestive of the presence of xyloglucans and arabinoxylans, in which the higher frequencies at 1171, 1121 and $1040 \mathrm{~cm}^{-1}$ are characteristic of xylans [45], the wavenumber $930 \mathrm{~cm}^{-1}$ is attributed to ring vibration and $891 \mathrm{~cm}^{-1}$ attributed to stretching of the $\beta$-anomeric link in xyloglucans [47]. The presence of arabinoxylans is corroborated by the aforementioned peaks characteristic of xylans and the peaks at $1049 \mathrm{~cm}^{-1}$, associated with linear and branched $(1 \rightarrow 4)-\beta$-xylan, and $955 \mathrm{~cm}^{-1}$, characteristic of disubstituted xylose residues in arabinoxylans [48]. 


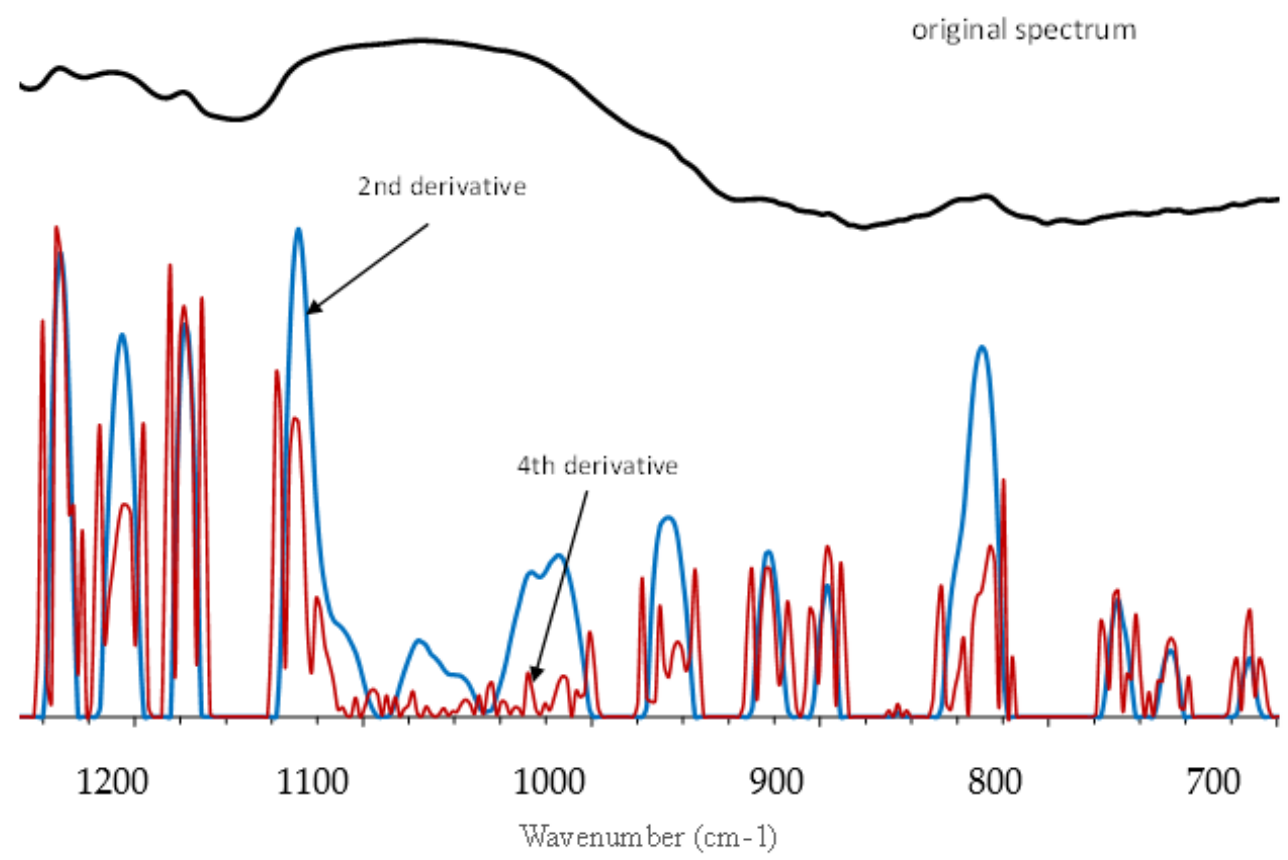

Figure 3. Fourier transform infrared (FTIR) spectrum for blanched coffee husks (black line) and its second (blue line) and fourth (red line) derivatives.

In general, samples comprising mostly the outer skin and pulp (CH1) showed values for TEP, CGA, PCA, NEP, bioaccessibility of phenolics, trigonelline, and some monosaccharides contents (i.e., arabinose, mannose, glucose, and myo-inositol) higher than those of samples comprising mostly parchment ( $\mathrm{CH} 2)$, confirming its highest nutritional and bioactive potential as food ingredient. Despite the loss of some compounds (TEP, PCA, caffeine, and trigonelline) by heat treatment, others could be better preserved (NEP and CGA). However, significant amounts of TEP, PCA, caffeine, and trigonelline could be maintained even after blanching. Considering industrial production, the use of blanched husks as a food ingredient would be more favorable for product conservation due to its microbiological load reduction and enzyme inactivation. For these reasons, $\mathrm{CH} 1 \mathrm{~b}$ was selected to be chemically characterized and evaluated for its technological potential, antioxidant capacity, and microstructure.

\subsection{Chemical, Physical, and Technological Properties}

The proximal composition of $\mathrm{CH} 1 \mathrm{~b}$ (Table 3 ) was determined and respective values for fat $(5.01 \pm 0.12 \mathrm{~g} / 100 \mathrm{~g})$, ash $(5.20 \pm 0.08 \mathrm{~g} / 100 \mathrm{~g})$, crude protein $(10.30 \pm 0.01 \mathrm{~g} / 100 \mathrm{~g})$ and TDF $(65.83 \pm 1.68 \mathrm{~g} / 100 \mathrm{~g})$ were higher than those determined for other fruit byproducts, such as buriti [28] and pequi [26] peels. Moreover, TDF values reported for coffee pulp and husks by Murthy and Naidu [52] were also lower than the herein determined. These variations are expected due to the inherent differences in coffee cultivars and in the techniques used in the by-product's treatment. Lower TDF contents determined by Murthy and Naidu [52] for coffee pulp and husks ( $28 \pm 43 \mathrm{~g} / 100 \mathrm{~g})$ were probably the result of fiber degradation caused by high pressures and high temperatures applied over a long period (around $30 \mathrm{~min}$ ). $\mathrm{CH} 1 \mathrm{~b}$ showed similar characteristics of commercialized fiber products (TDF above $50 \%$ and moisture below $9 \%$ ) even after blanching treatment. Thus, it can be an interesting alternative to be used as a dietary fiber source in the food industry. 
Table 3. Centesimal composition of $\mathrm{CH} 1 \mathrm{~b}$.

\begin{tabular}{|c|c|c|c|c|c|c|c|c|}
\hline \multicolumn{9}{|c|}{ Centensimal Composition } \\
\hline $\begin{array}{l}\text { Moisture } \\
\left(\mathrm{g} .100 \mathrm{~g}^{-1}\right)\end{array}$ & $\begin{array}{c}\text { Protein } \\
\left(\mathrm{g} .100 \mathrm{~g}^{-1}\right)\end{array}$ & $\begin{array}{c}\text { Fat } \\
\left(\mathrm{g} .100 \mathrm{~g}^{-1}\right)\end{array}$ & $\begin{array}{c}\text { Ash } \\
\left(\mathrm{g} .100 \mathrm{~g}^{-1}\right)\end{array}$ & $\begin{array}{c}\text { TDF } \\
\left(\mathrm{g} .100 \mathrm{~g}^{-1}\right)\end{array}$ & $\begin{array}{c}\text { IDF } \\
\left(\mathrm{g} .100 \mathrm{~g}^{-1}\right)\end{array}$ & $\begin{array}{c}\text { SDF } \\
\left(\mathrm{g} .100 \mathrm{~g}^{-1}\right)\end{array}$ & $\begin{array}{l}\text { Pectin Content } \\
\quad\left(\mathrm{g} .100 \mathrm{~g}^{-1}\right)\end{array}$ & $\underset{(\%)}{\text { Pectin in SDF }}$ \\
\hline $5.50 \pm 0.05$ & $10.03 \pm 0.01$ & $5.01 \pm 0.12$ & $5.20 \pm 0.08$ & $65.83 \pm 1.68$ & $58.69 \pm 0.45$ & $7.97 \pm 0.36$ & $6.58 \pm 0.01$ & $82.91 \pm 2.44$ \\
\hline
\end{tabular}

The soluble and insoluble characteristics of fibers affect their technological functionality and physiological effects [28]. IDF content of CH1b (58.69 g/100 g) is also high compared to those of other by-products (pequi peel: 30.3-33.94 g/100 $\mathrm{g}$ and buriti peel: $47.91-49.21 \mathrm{~g} / 100 \mathrm{~g}$ ) [26,28]. A high IDF content may be associated with a large amount of total non-digestible carbohydrates and low available carbohydrate content. $\mathrm{CH} 1 \mathrm{~b}$ mostly comprises IDF ( $>50 \%)$; therefore, it might present pronounced effects on intestinal regulation and stool volume since these effects are associated with the consumption of products with high contents of insoluble fibers. SDF is also attractive due to its capacity to decrease plasma cholesterol and glycemic response, and its prebiotic action [53]. SDF of CH1b (7.97 \pm 0.36$)$ mostly comprises pectin $(\sim 83 \%)$ and its content is comparable to those of apple, peach, and tomato $(\sim 6-7.5 \mathrm{~g} / 100 \mathrm{~g})$ [53]. Pectin is a soluble fiber widely applied as a gelling agent and stabilizer in food matrices.

CH1b presented high antioxidant activity $(755.9 \pm 47.97 \mu \mathrm{mol}$ Trolox/g; $175.78 \pm 0.49 \mu \mathrm{mol} \mathrm{Fe} \mathrm{SO}_{4} / \mathrm{g}$ ). The antioxidant activities of $\mathrm{CH} 1 \mathrm{~b}$ determined by different techniques were higher than or similar to those of many matrices known as a potent antioxidant, such acai $\left(220 \pm 32.9 \mu \mathrm{mol} \mathrm{Fe}{ }_{2} \mathrm{SO}_{4} / \mathrm{g}\right)$ and spent coffee grounds $(180 \pm 57 \mu \mathrm{mol}$ Trolox/g) $[54,55]$. Such antioxidant activity of $\mathrm{CH} 1 \mathrm{~b}$ can be attributed its high contents of polysaccharides [56] and of extractable phenolics (904.74 mg GAE/100 g).

The technological properties that render a by-product suitable for utilization as food ingredient were determined for $\mathrm{CH} 1 \mathrm{~b}$ and are presented in Table 4 . Luminosity of $\mathrm{CH} 1 \mathrm{~b}$ $(\mathrm{L}=44.93 \pm 0.18)$ was low compared to other by-products obtained from fruit peels (buriti: $53.13<\mathrm{L}^{*}<62.38$ and pequi: 55.2) [54,55]. The low luminosity of $\mathrm{CH} 1$ can be partially attributed to the degradation of anthocyanins by the action of enzymes (peroxidases and polyphenoloxidases), liberated by the damaged cells of the outer skin and pulp during handling and drying, or by other oxidizing agents, such as oxygen [18]. Despite this, coffee husks flours were clearer than other by-products flours [54,55]. This characteristic is desirable in applications where food product color should not be changed by adding an ingredient. Chroma $\left(\mathrm{c}^{*}\right)$ and hue angle $(\mathrm{h})$ values for $\mathrm{CH} 1 \mathrm{~b}$ are in the same range of those for other fiber-rich by-products flours [54,55], with $\mathrm{h}^{\circ}$ indicating a predominance of yellow over red $\left(>45^{\circ}\right)$.

Table 4. Technological properties and antioxidant capacity of $\mathrm{CH} 1 \mathrm{~b}$.

\begin{tabular}{|c|c|c|c|c|c|c|c|}
\hline \multicolumn{6}{|c|}{ Technological Properties } & \multicolumn{2}{|c|}{ Antioxidant Capacity } \\
\hline $\begin{array}{l}\text { Luminosity } \\
\text { (L) }\end{array}$ & $\begin{array}{c}\text { Hue Angle } \\
\text { (h) }\end{array}$ & $\begin{array}{c}\text { Color } \\
\text { Saturation (c) }\end{array}$ & $\begin{array}{c}\text { OHC } \\
\left.\text { (g oil. } g^{1}\right)\end{array}$ & $\begin{array}{c}\text { SWC } \\
\left(\mathrm{mL}^{-1} \mathrm{~g}^{-1}\right)\end{array}$ & $\begin{array}{c}\text { WHC } \\
\left.\text { (g water.g }^{-1}\right)\end{array}$ & $\begin{array}{c}\text { ABTS } \\
(\mu \mathrm{mol} \\
\left.\text { Trolox.g }{ }^{-1}\right)\end{array}$ & $\begin{array}{c}\text { FRAP } \\
(\mu \mathrm{mol} \\
\left.\mathrm{Fe}_{2} \mathrm{SO}_{4} \cdot \mathrm{g}^{-1}\right)\end{array}$ \\
\hline $44.93 \pm 0.18$ & $67.28 \pm 0.09$ & $25.79 \pm 0.10$ & $5.21 \pm 0.15$ & $\begin{array}{c}8.75 \pm 0.35 \\
(\mathrm{pH} 1.5) \\
6.87 \pm 0.03^{\mathrm{a}} \\
(\mathrm{pH} 7.0) \\
9.02 \pm 0.37^{\mathrm{b}} \\
(\mathrm{pH} 8.5) \\
10.60 \pm 0.52^{\mathrm{c}}\end{array}$ & $\begin{array}{c}4.08 \pm 0.05 \\
(\mathrm{pH} 1.5) \\
4.12 \pm 0.02^{\mathrm{a}} \\
(\mathrm{pH} 7.0) \\
4.16 \pm 0.01^{\mathrm{b}} \\
(\mathrm{pH} 8.5) \\
4.19 \pm 0.04 \mathrm{~b}\end{array}$ & $755.9 \pm 47.97$ & $175.78 \pm 0.49$ \\
\hline
\end{tabular}

Mean \pm standard deviation $(n=3)$. Different letters in the same line indicate that values are significantly different $(p>0.05)$. OHC-Oil holding capacity; SWC-Swelling capacity; WHC-Water holding capacity. 
WHC represents the water quantity that remains in hydrated flours after application of an external force and SWC indicates how much the fiber matrix increases in size when water is absorbed. SWC value for $\mathrm{CH} 1 \mathrm{~b}(8.75 \pm 0.35 \mathrm{~mL} / \mathrm{g})$ was higher than those of by-products of buriti $(3.7 \mathrm{~mL} / \mathrm{g})$, mango $(4.6 \mathrm{~mL} / \mathrm{g})$, passion fruit $(7.2 \mathrm{~mL} / \mathrm{g})$, pineapple $(6.6 \mathrm{~mL} / \mathrm{g})$, and guava $(1.4 \mathrm{~mL} / \mathrm{g})$, whereas WHC value $(4.08 \mathrm{~g} / \mathrm{g})$ was higher than those of buriti blanched peel $(1.14 \mathrm{~g} / \mathrm{g})$ and pequi peel $(3.74-3.98 \mathrm{~g} / \mathrm{g})[54,55,57]$. High WHC and SWC values are usually associated with high levels of SDF because soluble fibers present better hydration properties than insoluble ones [58]. In human bodies, fiber swelling promoted by hydration increases fecal bulking and decreases its transit time, which can prevent colon cancer [59].

Unlike water hydration properties, oil retention capacity is related to the presence of hydrophobic groups in the food matrix. Proteins are characterized by presenting hydrophilic and hydrophobic functional groups. These hydrophobic groups can be associated physicochemically with non-polar chains of the oil and promote their retention. Therefore, the higher the protein content, the greater the oil holding capacity. As the protein content of $\mathrm{CH} 1 \mathrm{~b}$ was higher than those of other fruit peel by-products, $\mathrm{OHC}$ value for $\mathrm{CH} 1 \mathrm{~b}$ was consequently higher $[54,55]$. High $\mathrm{OHC}$ values favor flavor retention ability and emulsification capacity of by-products, preclude loss of fat during processing, and bring health benefits associated with the reduction of plasma cholesterol [59].

Regarding SWC and WHC results for samples evaluated under physiological conditions (isotonic solutions at $37{ }^{\circ} \mathrm{C}$ at different $\mathrm{pH}$ ), hydration properties of $\mathrm{CH} 1 \mathrm{~b}$ increased with increasing $\mathrm{pH}$ from 1.5 to 8.5 . SWC values were $6.87 \pm 0.03,9.02 \pm 0.37$ and $10.60 \pm 0.52 \mathrm{~mL} / \mathrm{g}$ respectively for $\mathrm{pH} 1.5,7.0$ and 8.5 ; and WHC values were $4.12 \pm 0.02$, $4.16 \pm 0.01$ and $4.19 \pm 0.04 \mathrm{~g} \mathrm{H}_{2} \mathrm{O} / \mathrm{g}$ respectively for $\mathrm{pH} 1.5,7.0$ and 8.5. The progressive ionization of the chains of the different polysaccharides present in the $\mathrm{CH} 1 \mathrm{~b}$, mostly pectin $(6.58 \pm 0.01 \mathrm{~g} / 100 \mathrm{~g} ; 83 \%$ of SDF) contributed to the increase of its hydration properties. Carboxylic groups and carboxylic esters are the main functional groups of pectin. Thus, the ionization of carboxylic groups in alkaline medium led to an expansion of the pectin structure due to effects of electrostatic repulsion between negative charges present in the chains [60].

The morphology of $\mathrm{CH} 1 \mathrm{~b}$ was observed by scanning electron microscopy (Figure 4). $\mathrm{CH} 1 \mathrm{~b}$ exhibited irregular surfaces with fragments or symmetric particles ranging in size from 5 to $40 \mu \mathrm{m}$. The particle size is the most important physical parameter defining flour behavior. Smaller particle sizes are expected to improve the coarse sensory properties of the final products in which the flours are used as ingredients. The particle sizes herein determined for $\mathrm{CH} 1 \mathrm{~b}$ flours are in the same range of those of wheat bran particles $(0.5-100 \mu \mathrm{m})$ that were successfully applied by Song et al. [61] in food products to replace wheat flour. Considering the antioxidant capacity and all technological properties evaluated, $\mathrm{CH} 1 \mathrm{~b}$ flour showed great potential for use as a food ingredient. 


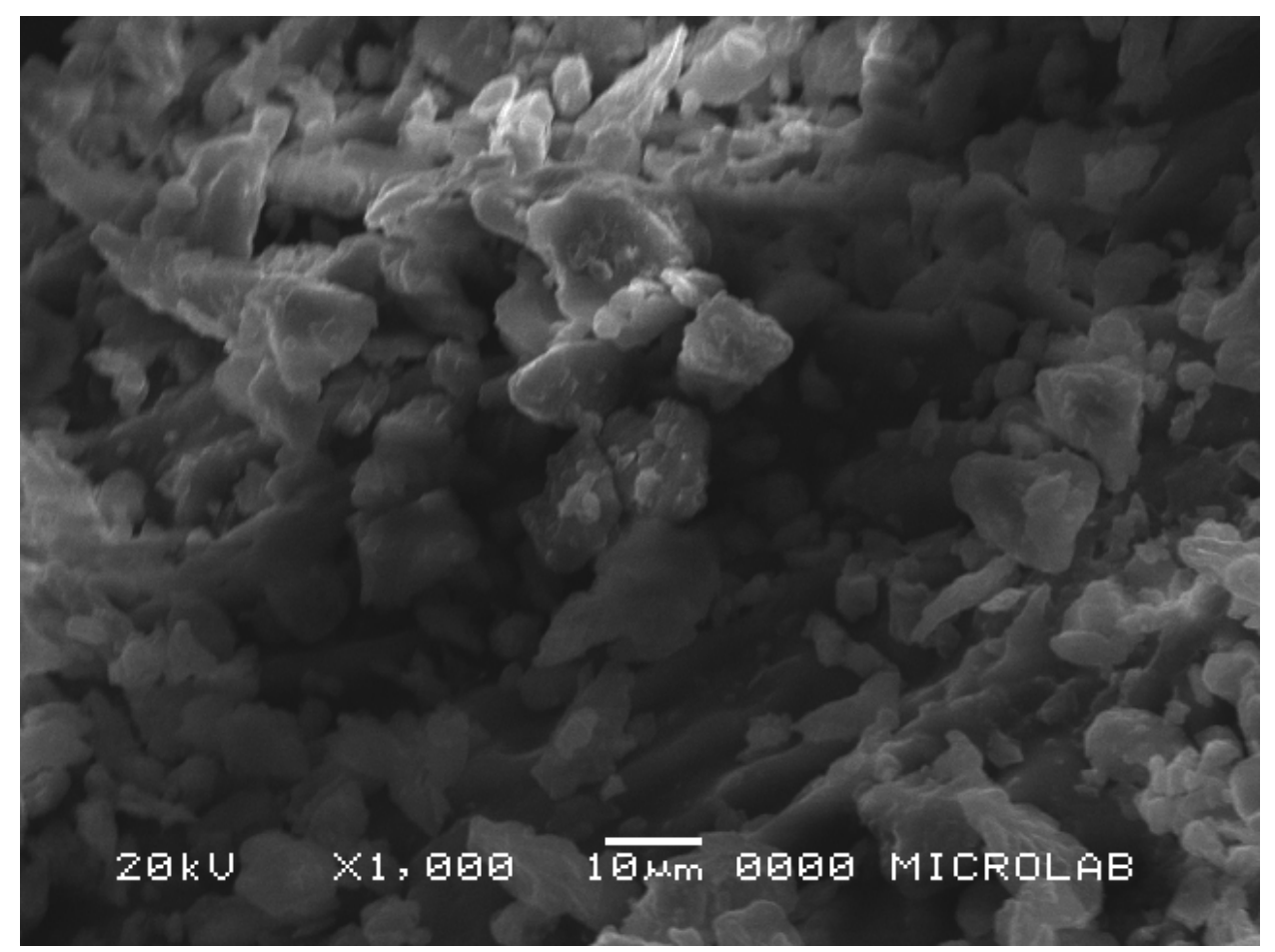

Figure 4. Scanning electron microscopy image of blanched coffee husks comprised mostly of outer skin (CH1b).

\section{Conclusions}

The chemical composition of coffee husks was investigated. Blanching of coffee husks had a positive effect on the bioactive potential of these by-products demonstrating their potential for use as a functional food ingredient. Coffee husks $(\mathrm{CH})$ comprising mostly outer skin and pulp (CH1) showed higher bioactive potential and bioaccessibility of phenolics than $\mathrm{CH}$ comprising mostly parchment $(\mathrm{CH} 2)$. NEP contents were higher than TEP ones, indicating most of the phenolics of $\mathrm{CH}$ were trapped in the plant matrix. Blanching treatment led to the loss of some compounds (TEP, PCA, caffeine, and trigonelline), but others (NEP and CGA) were better preserved, depending on the level of interaction of the compounds with the matrix and their thermal stability. The polysaccharide fraction was characterized with cellulose, pectic polysaccharides, arabinogalactans type II, galactomannans, xyloglucans and arabinoxylans being tentatively identified. The blanched CH1 sample (CH1b) showed significant potential to be used as ingredient in food products since it had similar characteristics of commercialized fiber products, predominantly yellow color $(\mathrm{h}=67.28)$ and small sized particles $(5-40 \mu \mathrm{m})$. Besides, its values for antioxidant, hydration properties, and oil holding capacity were higher than those of other fruit by-products, which were associated with the presence of phenolic compounds, insoluble fibers, and proteins, respectively. Results confirmed the high nutritional and bioactive potential of coffee husks.

Author Contributions: Conceptualization, L.B.C., A.S.F. and L.S.O.; methodology, L.B.C., J.C.M., A.S.F. and L.S.O.; investigation, L.B.C. and J.C.M.; data curation, L.B.C. and J.C.M.; formal analysis, L.B.C. and J.C.M.; writing-original draft preparation, L.B.C.; writing-review and editing, A.S.F. and L.S.O.; funding acquisition, L.S.O.; supervision, L.S.O.; project administration, L.S.O. All authors have read and agreed to the published version of the manuscript.

Funding: This research was funded by Brazilian Government Agencies: CNPq and CAPES.

Institutional Review Board Statement: Not applicable.

Informed Consent Statement: Not applicable. 
Data Availability Statement: The data presented in this study are available on request from the corresponding author.

Conflicts of Interest: The authors declare that they have no known competing financial interests or personal relationship that could have appeared to influence the work reported in this paper.

\section{References}

1. Campos-Vega, R.; Loarca-Piña, G.; Vergara-Castañeda, H.A.; Oomah, B.D. Spent coffee grounds: A review on current research and future prospects. Trends Food Sci. Technol. 2015, 45, 24-36. [CrossRef]

2. ICO_International Coffee Organization. World Coffee Production. 2019. Available online: http://www.ico.org/pt/trade_ statisticsp.asp (accessed on 1 December 2019).

3. Franca, A.S.; Oliveira, L.S. Coffee processing solid wastes: Current uses and future perspectives. In Agricultural Wastes; Ashworth, G.S., Azevedo, P., Eds.; Nova Science Publishers Inc.: New York, NY, USA, 2009; pp. 155-189.

4. Franca, A.S.; Oliveira, L.S. Coffee. In Integrated Processing Technologies for Food and Agricultural By-Products; Elsevier: London, UK, 2019; pp. 413-438. [CrossRef]

5. Pleissner, D.; Neu, A.-K.; Mehlmann, K.; Schneider, R.; Quintero, G.I.P.; Venus, J. Fermentative lactic acid production from coffee pulp hydrolysate using Bacillus coagulans at laboratory and pilot scales. Bioresour. Technol. 2016, 218, 167-173. [CrossRef] [PubMed]

6. Moreira, M.D.; Melo, M.M.; Coimbra, J.M.; dos Reis, K.C.; Schwan, R.; Silva, C.F. Solid coffee waste as alternative to produce carotenoids with antioxidant and antimicrobial activities. Waste Manag. 2018, 82, 93-99. [CrossRef]

7. Iriondo-DeHond, A.; García, N.A.; Fernandez-Gomez, B.; Guisantes-Batan, E.; Escobar, F.V.; Blanch, G.P.; Andres, M.I.S.; SanchezFortun, S.; del Castillo, M.D. Validation of coffee by-products as novel food ingredients. Innov. Food Sci. Emerg. Technol. 2019, 51, 194-204. [CrossRef]

8. Parra-Campos, A.; Ordóñez-Santos, L.E. Natural pigment extraction optimization from coffee exocarp and its use as a natural dye in French meringue. Food Chem. 2019, 285, 59-66. [CrossRef]

9. Sarrouh, B.; De Souza, R.O.A.; Florindo, R.H.D.S.; Lofrano, R.C.Z.; De Oliveira, A.M. Extraction and identification of biomolecules from lignin alkaline hydrolysate from coffee husk. Waste Biomass Valoriz. 2020, 12, 787-794. [CrossRef]

10. Klingel, T.; Kremer, J.I.; Gottstein, V.; De Rezende, T.R.; Schwarz, S.; Lachenmeier, D.W. A review of coffee by-products including leaf, flower, cherry, husk, silver skin, and spent grounds as novel foods within the European Union. Foods 2020, 9, 665. [CrossRef]

11. Gouvea, B.M.; Torres, C.; Franca, A.S.; Oliveira, L.S.; Oliveira, E.S. Feasibility of ethanol production from coffee husks. Biotechnol. Lett. 2009, 31, 1315-1319. [CrossRef] [PubMed]

12. Bekalo, S.A.; Reinhardt, H.-W. Fibers of coffee husk and hulls for the production of particleboard. Mater. Struct. 2010, 43, 1049-1060. [CrossRef]

13. Cerda, A.; Gea, T.; García, M.D.C.V.; Sánchez, A. Towards a competitive solid state fermentation: Cellulases production from coffee husk by sequential batch operation and role of microbial diversity. Sci. Total Environ. 2017, 589, 56-65. [CrossRef]

14. Oliveira, F.D.C.; Srinivas, K.; Helms, G.L.; Isern, N.G.; Cort, J.R.; Gonçalves, A.R.; Ahring, B.K. Characterization of coffee (Coffea arabica) husk lignin and degradation products obtained after oxygen and alkali addition. Bioresour. Technol. 2018, 257, 172-180. [CrossRef]

15. Ramirez-Martinez, J.R. Phenolic compounds in coffee pulp: Quantitative determination by HPLC. J. Sci. Food Agric. 1988, 43, 135-144. [CrossRef]

16. Clifford, M.; Ramirez-Martinez, J. Phenols and caffeine in wet-processed coffee beans and coffee pulp. Food Chem. 1991, 40, 35-42. [CrossRef]

17. Ramirez-Coronel, M.A.; Marnet, N.; Kolli, V.S.K.; Roussos, S.; Guyot, S.; Augur, C. Characterization and estimation of proanthocyanidins and other phenolics in coffee pulp (Coffea arabica) by thiolysis-high-performance liquid chromatography. J. Agric. Food Chem. 2004, 52, 1344-1349. [CrossRef] [PubMed]

18. Prata, E.R.; Oliveira, L.S. Fresh coffee husks as potential sources of anthocyanins. LWT 2007, 40, 1555-1560. [CrossRef]

19. Mullen, W.; Nemzer, B.; Stalmach, A.; Ali, S.; Combet, E. Polyphenolic and hydroxycinnamate contents of whole coffee fruits from China, India, and Mexico. J. Agric. Food Chem. 2013, 61, 5298-5309. [CrossRef] [PubMed]

20. Rodsamran, P.; Sothornvit, R. Extraction of phenolic compounds from lime peel waste using ultrasonic-assisted and microwaveassisted extractions. Food Biosci. 2019, 28, 66-73. [CrossRef]

21. Arranz, S.; Saura-Calixto, F.; Shaha, S.; Kroon, P. High Contents of nonextractable polyphenols in fruits suggest that polyphenol contents of plant foods have been underestimated. J. Agric. Food Chem. 2009, 57, 7298-7303. [CrossRef]

22. Zurita, J.; Díaz-Rubio, M.E.; Calixto, F.D.S. Improved procedure to determine non-extractable polymeric proanthocyanidins in plant foods. Int. J. Food Sci. Nutr. 2012, 63, 936-939. [CrossRef]

23. Renard, C.M.; Watrelot, A.A.; Le Bourvellec, C. Interactions between polyphenols and polysaccharides: Mechanisms and consequences in food processing and digestion. Trends Food Sci. Technol. 2017, 60, 43-51. [CrossRef]

24. Dutra, R.L.T.; Dantas, A.M.; Marques, D.D.A.; Batista, J.D.F.; Meireles, B.; Cordeiro, M.T.D.M.; Magnani, M.; Borges, G. Bioaccessibility and antioxidant activity of phenolic compounds in frozen pulps of Brazilian exotic fruits exposed to simulated gastrointestinal conditions. Food Res. Int. 2017, 100, 650-657. [CrossRef] 
25. Perrone, D.; Donangelo, C.M.; Farah, A. Fast simultaneous analysis of caffeine, trigonelline, nicotinic acid and sucrose in coffee by liquid chromatography-mass spectrometry. Food Chem. 2008, 110, 1030-1035. [CrossRef] [PubMed]

26. Leão, D.P.; Franca, A.S.; Oliveira, L.S.; Bastos, R.; Coimbra, M.A. Physicochemical characterization, antioxidant capacity, total phenolic and proanthocyanidin content of flours prepared from pequi (Caryocar brasilense Camb.) fruit by-products. Food Chem. 2017, 225, 146-153. [CrossRef]

27. AOAC-Association of Official Analytical Chemists. Official Methods of Analysis of the Association of Analytical Chemists, 16th ed.; Association of Official Analytical Chemists: Washington, DC, USA, 2005.

28. Resende, L.M.; Franca, A.S.; Oliveira, L.S. Buriti (Mauritia flexuosa L. f.) fruit by-products flours: Evaluation as source of dietary fibers and natural antioxidants. Food Chem. 2019, 270, 53-60. [CrossRef] [PubMed]

29. Vasco, C.; Ruales, J.; Kamal-Eldin, A. Total phenolic compounds and antioxidant capacities of major fruits from Ecuador. Food Chem. 2008, 111, 816-823. [CrossRef]

30. Pérez-Jiménez, J.; Saura-Calixto, F. Fruit peels as sources of non-extractable polyphenols or macromolecular antioxidants: Analysis and nutritional implications. Food Res. Int. 2018, 111, 148-152. [CrossRef] [PubMed]

31. Xie, L.; Guo, J.; Zhang, Y.; Shi, S. efficient determination of protocatechuic acid in fruit juices by selective and rapid magnetic molecular imprinted solid phase extraction coupled with HPLC. J. Agric. Food Chem. 2014, 62, 8221-8228. [CrossRef]

32. Yun, N.; Kang, J.; Lee, S. Protective effects of chlorogenic acid against ischemia/reperfusion injury in rat liver: Molecular evidence of its antioxidant and anti-inflammatory properties. J. Nutr. Biochem. 2012, 23, 1249-1255. [CrossRef]

33. Rebollo-Hernanz, M.; Zhang, Q.; Aguilera, Y.; Martín-Cabrejas, M.A.; De Mejia, E.G. Relationship of the phytochemicals from coffee and cocoa by-products with their potential to modulate biomarkers of metabolic syndrome in vitro. Antioxidants 2019, 8, 279. [CrossRef]

34. Phan, A.; Netzel, G.; Wang, D.; Flanagan, B.M.; D’Arcy, B.R.; Gidley, M.J. Binding of dietary polyphenols to cellulose: Structural and nutritional aspects. Food Chem. 2016, 171, 388-396. [CrossRef]

35. Liu, X.; Le Bourvellec, C.; Renard, C.M.G.C. Interactions between cell wall polysaccharides and polyphenols: Effect of molecular internal structure. Compr. Rev. Food Sci. Food Saf. 2020, 19, 3574-3617. [CrossRef]

36. Pinarli, B.; Karliga, E.S.; Ozkan, G.; Capanoglu, E. Interaction of phenolics with food matrix: In vitro and in vivo approaches. Mediterr. J. Nutr. Metab. 2020, 13, 63-74. [CrossRef]

37. Benitez, V.; Rebollo-Hernanz, M.; Hernanz, S.; Chantres, S.; Aguilera, Y.; Martin-Cabrejas, M.A. Coffee parchment as a new dietary fiber ingredient: Functional and physiological characterization. Food Res. Int. 2019, 122, 105-113. [CrossRef] [PubMed]

38. Reichembach, L.H.; Petkowicz, C.L.D.O. Extraction and characterization of a pectin from coffee (Coffea arabica L.) pulp with gelling properties. Carbohydr. Polym. 2020, 245, 116473. [CrossRef] [PubMed]

39. Mohamadi, N.; Sharififar, F.; Pournamdari, M.; Ansari, M. A review on biosynthesis, analytical techniques, and pharmacological activities of trigonelline as a plant alkaloid. J. Diet. Suppl. 2017, 15, 207-222. [CrossRef] [PubMed]

40. Simões, J.; Maricato, E.; Nunes, F.M.; Domingues, M.R.; Coimbra, M.A. Thermal stability of spent coffee ground polysaccharides: Galactomannans and arabinogalactans. Carbohydr. Polym. 2014, 101, 256-264. [CrossRef] [PubMed]

41. Ballesteros, L.F.; Cerqueira, M.; Teixeira, J.; Mussatto, S.I. Characterization of polysaccharides extracted from spent coffee grounds by alkali pretreatment. Carbohydr. Polym. 2015, 127, 347-354. [CrossRef]

42. Masuda, T.; Kawano, A.; Kitahara, K.-I.; Nagashima, K.; Aikawa, Y.; Arai, S. Quantitative determination of sugars and myoinositol in citrus fruits grown in Japan using high-performance anion-exchange chromatography. J. Nutr. Sci. Vitaminol. 2003, 49, 64-68. [CrossRef]

43. Ruiz-Aceituno, L.; Rodríguez-Sánchez, S.; Sanz, J.; Sanz, M.; Ramos, L. Optimization of pressurized liquid extraction of inositols from pine nuts (Pinus pinea L.). Food Chem. 2014, 153, 450-456. [CrossRef]

44. Harvey, B.H.; Brink, C.B.; Seedat, S.; Stein, D. Defining the neuromolecular action of myo-inositol application to obsessivecompulsive disorder. Prog. Neuro-Psychopharmacol. Biol. Psychiatry 2002, 26, 21-32. [CrossRef]

45. Coimbra, M.A.; Barros, A.; Rutledge, D.N.; Delgadillo, I. FTIR spectroscopy as a tool for the analysis of olive pulp cell-wall polysaccharide extracts. Carbohydr. Res. 1999, 317, 145-154. [CrossRef]

46. Kacuráková, M.; Capek, P.; Sasinková, V.; Wellner, N.; Ebringerova, A. FT-IR study of plant cell wall model compounds: Pectic polysaccharides and hemicelluloses. Carbohydr. Polym. 2000, 43, 195-203. [CrossRef]

47. Szymanska-Chargot, M.; Chylinska, M.; Kruk, B.; Zdunek, A. Combining FT-IR spectroscopy and multivariate analysis for qualitative and quantitative analysis of the cell wall composition changes during apples development. Carbohydr. Polym. 2015, 115, 93-103. [CrossRef] [PubMed]

48. Robert, P.; Marquis, M.; Barron, C.; Guillon, F.; Saulnier, L. FT-IR investigation of cell wall polysaccharides from cereal grains. Arabinoxylan infrared assignment. J. Agric. Food Chem. 2005, 53, 7014-7018. [CrossRef]

49. Fernando, S.; Sanjeewa, K.K.A.; Samarakoon, K.W.; Lee, W.W.; Kim, H.-S.; Kim, E.-A.; Gunasekara, U.K.D.S.S.; Abeytunga, D.T.U.; Nanayakkara, C.; De Silva, E.D.; et al. FTIR characterization and antioxidant activity of water soluble crude polysaccharides of Sri Lankan marine algae. ALGAE 2017, 32, 75-86. [CrossRef]

50. Estevez, J.M.; Fernández, P.V.; Kasulin, L.; Dupree, P.; Ciancia, M. Chemical and in situ characterization of macromolecular components of the cell walls from the green seaweed Codium fragile. Glycobiology 2009, 19, 212-228. [CrossRef]

51. Pawar, H.A.; Lalitha, K. Isolation, purification and characterization of galactomannans as an excipient from Senna tora seeds. Int. J. Biol. Macromol. 2014, 65, 167-175. [CrossRef] 
52. Murthy, P.S.; Naidu, M.M. Recovery of phenolic antioxidants and functional compounds from coffee industry by-products. Food Bioprocess. Technol. 2010, 5, 897-903. [CrossRef]

53. Elleuch, M.; Bedigian, D.; Roiseux, O.; Besbes, S.; Blecker, C.; Attia, H. Dietary fibre and fibre-rich by-products of food processing Characterisation, technological functionality and commercial applications: A review. Food Chem. 2011, 124, 411-421. [CrossRef]

54. Páscoa, R.; Magalhaes, L.; Lopes, J. FT-NIR spectroscopy as a tool for valorization of spent coffee grounds: Application to assessment of antioxidant properties. Food Res. Int. 2013, 51, 579-586. [CrossRef]

55. Rufino, M.D.S.M.; Alves, R.E.; de Brito, E.S.; Pérez-Jiménez, J.; Saura-Calixto, F.; Mancini-Filho, J. Bioactive compounds and antioxidant capacities of 18 non-traditional tropical fruits from Brazil. Food Chem. 2010, 121, 996-1002. [CrossRef]

56. Wang, J.; Hu, S.; Nie, S.; Yu, Q.; Xie, M. Reviews on mechanisms of in vitro antioxidant activity of polysaccharides. Oxid. Med. Cell. Longev. 2016, 2016, 1-13. [CrossRef]

57. Martínez, R.; Torres, P.; Meneses, M.; Figueroa, J.G.; Pérez-Alvarez, J.A.; Viuda-Martos, M. Chemical, technological and in vitro antioxidant properties of mango, guava, pineapple and passion fruit dietary fibre concentrate. Food Chem. 2012, 135, 1520-1526. [CrossRef] [PubMed]

58. Viuda-Martos, M.; Ruiz-Navajas, Y.; Martin-Sánchez, A.; Sánchez-Zapata, E.; Fernández-López, J.; Sendra, E.; Sayas-Barberá, E.; Navarro, C.; Pérez-Álvarez, J. Chemical, physico-chemical and functional properties of pomegranate (Punica granatum L.) bagasses powder co-product. J. Food Eng. 2012, 110, 220-224. [CrossRef]

59. Kaczmarczyk, M.M.; Miller, M.; Freund, G.G. The health benefits of dietary fiber: Beyond the usual suspects of type 2 diabetes mellitus, cardiovascular disease and colon cancer. Metabolism 2012, 61, 1058-1066. [CrossRef] [PubMed]

60. Krishna, K.A.; Vishalakshi, B. Gellan gum-based novel composite hydrogel: Evaluation as adsorbent for cationic dyes. J. Appl. Polym. Sci. 2017, 134, 45527. [CrossRef]

61. Song, X.; Zhu, W.; Pei, Y.; Ai, Z.; Chen, J. Effects of wheat bran with different colors on the qualities of dry noodles. J. Cereal Sci. 2013, 58, 400-407. [CrossRef] 